\title{
Moral Intelligence: An Antidote to Examination Malpractices in Nigerian Schools
}

\author{
Olayiwola Idowu Olusola ${ }^{*}$, Ajayi, Oluwagbemiga Samson \\ Department of Educational Foundations and Counselling, Faculty of Education, Obafemi Awolowo University, Ile-Ife, Nigeria
}

Copyright (C) 2015 Horizon Research Publishing All rights reserved.

\begin{abstract}
Moral intelligence is the capacity to apply moral principles to one's own values, goals and actions (or the ability to see what is right and integrate it into one's life and actions) It is considered as the individual capacity to understand right from wrong, to have strong ethical convictions and to act on them to behave in the right and honourable. This study examined the level of moral intelligence among senior secondary school students in Osun State. It also investigated whether there is a relationship between moral intelligence and students' perception of examination malpractice as well as examined the influence of variables such as students' gender and family structure on their moral intelligence. The study adopted survey method. The sample size was 240 Senior Secondary School class two students (Mean Age $=15.62$, SD $=1.26$ )in Ife North Local Government Area of Osun state, Nigeria . Two instruments were used to collect data for the study. They were: Students' Moral Intelligence questionnaire adapted from Moral Competency Inventory (MCI) by Martin and Austin (2008) and Students Perceptions of Examination Malpractice in the Society (SPEM) which was adapted from Ejide (2005). Data collected were analyzed using descriptive statistics of frequency and percentage, Pearson Product Moment Correlation Test, t-test and ANOVA. The results showed that $2.6 \%$ of the students had low level of moral intelligence, $12.6 \%$ of them had moderate level, $38.7 \%$ of them had high level while $46.1 \%$ of the students had very high level of moral intelligence. Result also showed that moral intelligence significantly correlated with students' perception of examination malpractices $(\mathrm{N}=230, \mathrm{r}=-.371 \mathrm{p}$ $<0.05)$. Also, significant difference were found in male $(\mathrm{M}=86.27, \mathrm{SD}=14.144)$ and female students $(\mathrm{M}=80.87$, $\mathrm{SD}=16.61 ; \mathrm{t}(228)=2.637, \mathrm{p}=.009)$ moral intelligence while there was also a statistically significant difference at the $\mathrm{p}<.05$ level in moral intelligence scores for students under the five different living arrangement: $F(4,221)=3.90$, $\mathrm{p}=.004$. The result of Post-hoc comparisons using the Turkey HSD test indicated that the mean score for students living with mother only $(\mathrm{M}=77.18, \quad \mathrm{SD}=19.81)$ was significantly different from those living with father and mother together $(\mathrm{M}=85.89, \mathrm{SD}=14.39)$. Mean score for students living with father only $(\mathrm{M}=73.69, \mathrm{SD}=18.79)$ was significantly different from those living with father and
\end{abstract}

mother together $(\mathrm{M}=85.89, \mathrm{SD}=14.39)$. It therefore concludes that moral intelligence enhancement training could have positive and an enduring impact on their decision making process regarding involvement in examination malpractices.

\begin{abstract}
Keywords Moral Intelligence, Examination
Malpractices
\end{abstract}

\section{Introduction}

One of the ways through which the outcomes of a teaching and learning process could be ascertained is through examination. This is because examination constitutes the yardstick for determining the extent to which organizational goals and targets are being met. The quality of the products of an institution and parents expectations are being ascertained through examinations. Examination determines how much and to what extent investments in the educational sector are yielding desired dividends (Mkpa [1]). Examinations are also essential for maintenance of standards, for certification, motivation of students, control of curriculum and its delivery among other purposes. Aliyu et al [2] believed that an examination in an educational system is the primary measure to test a candidate's knowledge, skill and ability. Examinations have also been seen as a way to measure the effectiveness of teachers teaching strategies.

In Nigeria, examination is used for selection of people into educational institutions (for example, Unified Tertiary Matriculation Examination-UTME), job placement, promotions etc.).

As a result of so much emphasis on examination and importance attached to certificates acquisition, many candidates do violate examination regulations to pass qualifying examinations (Unigwe [3]). These unholy/dishonest practices among the testees or examinees have been described as examination malpractice(s). Examination malpractice or cheating in school has been defined by various authors. Bankole [4] described cheating in examination as any dishonest and deceitful move, arrangements and plans by a candidate, or school authority 
parents/ guardian or any examination body official to contravene examination rules/regulations to receive or give undue favour, so as to obtain undue reward for oneself or others in the educational system. Hiko [5] refers to examination malpractice as any illegal or unacceptable behaviour by anybody against examination rules and regulations at the time his knowledge or ability is being tested. Thus, it is the non-compliance to the rules and regulations controlling the conduct of an examination. In fact, Kpangban et al [6] and Money [7] reported that leakage of examination papers started in Nigeria as far back as 1914 with the senior Cambridge local examination question papers. Examination malpractice is not only peculiar to Nigeria, it occurs in almost every nations of the world. For instance, the Cable News Network [8] survey report indicated that $75 \%$ of high school students are involve in cheating. Olugbile [9] reported that the prevalence of examination malpractice in Nigeria is alarming. He supported this claim with the 2003 examination rating of the 36 states and FCT in Nigeria released by the Exam Ethics Project. In Nigeria, the results of 68,309 students that sat for the Unified Tertiary Matriculation Examination were withheld on the basis of examination malpractices (Vanguard, [10]). The opportunities to cheat during examinations have increased overtime and with considerable efforts (Onokoya, [11]). Reasons for and types of dishonesty have also been surveyed. These include ill preparation for the exams (Fagbemi, [12]); high stakes of examination personal factors, quota systems, low salary levels, inadequacies in public examinations, school facilities and teachers factors. Others are location of examination centres, personal factors (World Bank, [13]); examination anxiety and ignorance of the consequences of cheating (Mustapha, [14]); perception and attitude of students (Onokoya, [11]), etc.

Moral intelligence is the capacity to apply moral principles to one's own values, goals and actions (or the ability to see what is right and integrate it into one's life and actions). It involves integrity, responsibility, compassion and forgiveness (Lennick et al [15]). Borba [16] defines moral intelligence as the capacity to understand right from wrong, to have strong ethical convictions and to act on them to behave in the right and honourable way. Sulaimon [17] was of the opinion that moral teachings are detailed information, which concerns the principles of right and wrong behaviours. This in essence means that children that are trained in self-discipline and fed with useful instructions will reflect it in their everyday conduct. Since moral values involves applying ones principles into action, then we can then see that it correlates with cheating in examinations.

Olasehinde-Williams et al.[18] reported that significantly, more male than female respondents endorsed academic integrity in each of the three hypothetical situations. Also Leming [19] similarly found that females exhibited more cheating behaviour than males. This finding, however, contradicts those of Olasehinde-Williams et al.[20], One et al.[21] and Lobel [22] in which, higher proportions of male students manifested cheating tendency than females. Still, in some other studies, Braseth [23] as well as Evans [24] found no statistically significant differences between male and female students in cheating behaviour; just as no consistent influence of gender on endorsement of academic integrity.

The family lays the psychosocial, moral and spiritual foundations in the overall development of the child. While the father and mother's significant role in this cannot be over-emphasized. Studies on father-child relationship suggest that the presence of a father in the home influences significantly the development of a child (Uwaifo, [25]). This lend credence to earlier findings by Demuth et al.[26] that adolescents in single-mother or single-father families are significantly more delinquent than their counterparts residing with two biological, married parents. Children who live with a single parent or in stepfamilies are more likely to use and abuse illegal drugs, alcohol, or tobacco compared to children who live with both biological and adoptive parents (Bronte-Tinkew et al.[27]; Kelly [28]).

On gender differences in moral intelligence, women as observed by Freeman [29] rarely start wars, torture people or behave in other highly destructive ways; they are traditionally carers. Also, the results of the study by Hoseinpoor et al.[30] showed that girls have got higher forgiveness in compare to boys. It is interesting however to note that Self et al.[31] in their study discovered that there were no significant differences between genders on moral reasoning. This contradicted the findings by Self et al.[32] that gender differences in moral reasoning have frequently been found in other studies with medical students and with veterinary students. In those studies females consistently scored higher on the moral reasoning than did their male counterparts.

However, studies are limited on the moral intelligence of students and examination malpractices in Nigeria schools. Most of the studies carried out were dwelled majorly on examination malpractices vis-à-vis other factors aside moral intelligence.

The objectives of the present study were to:

a. determine the level of moral intelligence among senior secondary school students in Osun State,

b. examine whether there is a relationship between moral intelligence and students' perception of examination malpractice,

c. determine the influence of sex on students moral intelligence, and

d. determine the influence of family structure on students moral intelligence.

\section{Population and Sample}

The study adopted descriptive survey research design. The population consisted of all the secondary school students in Ife North, Ife Central and Ife East Local Government Areas (LGAs), Osun state, Nigeria. The sample size was 240 (Mean Age $=15.62$, SD $=1.26$ ) Senior Secondary School class two students. The procedures for selection were as follows: In each of the local government, two senior secondary schools were randomly selected. Senior Secondary School class two (SS 2) students were 
purposively selected from each school. The selection was purposive because the students in this class have spent five years in secondary school, have written an external examination in their Junior School and will be preparing for promotion examination to the terminal class where they will write another external examination (WASCE). Among the SS 2 students, 40 students were randomly selected from each of the school.

Table 1. Socio-Demographic Information of the Students

\begin{tabular}{|c|c|c|c|}
\hline Variable & Level & Frequency (f) & Percentage (\%) \\
\hline \multirow{4}{*}{$\begin{array}{l}\text { Age of the } \\
\text { Students }\end{array}$} & Less than $15 y r s$ & 42 & 18.3 \\
\hline & $15-16 y r s$ & 147 & 63.9 \\
\hline & $17 \mathrm{yrs}$ and above & 41 & 17.8 \\
\hline & Total & 230 & 100.0 \\
\hline \multirow{4}{*}{ Religion } & Christianity & 161 & 70.0 \\
\hline & Islam & 68 & 29.6 \\
\hline & No Response & 1 & .4 \\
\hline & Total & 230 & 100.0 \\
\hline \multirow{3}{*}{ Sex } & Male & 108 & 47.0 \\
\hline & Female & 122 & 53.0 \\
\hline & Total & 230 & 100.0 \\
\hline \multirow{5}{*}{$\begin{array}{c}\text { Area of } \\
\text { Discipline }\end{array}$} & Science & 148 & 64.3 \\
\hline & Social Science & 8 & 3.5 \\
\hline & Arts & 45 & 19.6 \\
\hline & Commercial & 29 & 12.6 \\
\hline & Total & 230 & 100.0 \\
\hline \multirow{7}{*}{$\begin{array}{l}\text { Whom do } \\
\text { you presently } \\
\text { live with }\end{array}$} & Mother only & 28 & 12.2 \\
\hline & Father Only & 16 & 7.0 \\
\hline & $\begin{array}{c}\text { Father and } \\
\text { mother together }\end{array}$ & 153 & 66.5 \\
\hline & Grandparent & 17 & 7.4 \\
\hline & Guardian & 12 & 5.2 \\
\hline & No Response & 4 & 1.7 \\
\hline & Total & 230 & 100.0 \\
\hline
\end{tabular}

The instrument for the study was Students' Moral Intelligence and Perception to Examination Questionnaire. The items on Students' Moral Intelligence questionnaire were adapted from Moral Competency Inventory (MCI) by Martin et al. [33] while items on Students Perceptions of Examination Malpractice in the Society (SPEM) were adapted from Ejide [34]. The MCI measures factors such as telling the truth, taking responsibility for personal choice, admitting mistakes and failures. The response options are "Very Inaccurate", "Moderately Inaccurate", "Neither Inaccurate nor Accurate", "Moderately Accurate", and "Very Accurate". Examples of items in the inventory are 'when things go wrong, I do not blame others', 'when I agree to do something, I always follow through' and "I tell the truth unless there is an overriding moral reason to withhold it. Section A of the adapted inventory solicited responses on the personal data of the respondents such as: Name of School, Class, Age, Sex, Religion, Family structure, Areas of discipline, Whom does student presently live with. There were 22 items in MCI subscale of the instrument which yielded reliability coefficient of 0.833 while ten items in SPEM subscale yielded reliability coefficient of 0.818 . Questionnaire on moral intelligence and perception of examination malpractice were administered on the selected students. Two hundred and thirty of the questionnaires were found to be valid for use.

\section{Results}

Research Objective 1: Determine the level of students' moral intelligence among senior secondary school students in Osun State

Table 2. Levels of Moral intelligence of senior secondary schools students in Osun State.

\begin{tabular}{|c|c|c|c|}
\hline $\begin{array}{c}\text { Moral } \\
\text { Intelligence }\end{array}$ & Frequency (f) & Percent (\%) & $\begin{array}{c}\text { Valid } \\
\text { Percent (\%) }\end{array}$ \\
\hline Low & 6 & 2.6 & 2.6 \\
\hline Moderate & 29 & 12.6 & 12.6 \\
\hline High & 89 & 38.7 & 38.7 \\
\hline Very High & 106 & 46.1 & 46.1 \\
\hline Total & 230 & 100.0 & 100.0 \\
\hline
\end{tabular}

Table 2 shows level of moral intelligence of secondary schools students. The result showed that $2.6 \%$ of the students had low level of moral intelligence, $12.6 \%$ of them had moderate level, $38.7 \%$ of them had high level while $46.1 \%$ of the students had very level of moral intelligence. There is an indication from this result that most of the students under this study possessed high level of moral intelligence.

Research Objective 2: Examine the relationship between students' moral intelligence and their perception of examination malpractices.

In order to achieve this objective, student's scores on moral intelligence were correlated with scores on perception of examination malpractices using Pearson product moment correlation statistics. The result is presented in table 3 below:

Table 3. Correlation between Moral Intelligence and Students' Perception of Examination Malpractices.

\begin{tabular}{|c|c|c|c|c|c|}
\hline Variables & $\mathrm{N}$ & $\overline{\mathrm{X}}$ & $\mathrm{SD}$ & $\mathrm{R}$ & $\mathrm{P}$ \\
\hline $\begin{array}{c}\text { Moral } \\
\begin{array}{c}\text { Intelligence/Perception } \\
\text { of Examination } \\
\text { Malpractices }\end{array}\end{array}$ & 230 & 83.404 & 15.700 & & \multirow{2}{*}{230} \\
\cline { 2 - 4 } & 23.787 & 9.293 & $\begin{array}{c}.000 \\
\mathrm{P}<.05\end{array}$ \\
\hline
\end{tabular}

Table 3 revealed that the correlation coefficient (r) between moral intelligence and perception of examination malpractices is -.371 . This value is found to be significant at 0.05 probability level. This suggested that there is an inverse and significant relationship between moral intelligence and perception of examination malpractices $(\mathrm{N}=230, \mathrm{r}=-.371 \mathrm{p}$ $<0.05)$. This result concluded that there is significant relationship between students' moral intelligence and their perception of examination malpractices.

Research Objective 3: Investigate if there is significant difference in moral intelligence of male and female students.

Table 4 showed an independent sample t-test conducted to determine the difference in moral intelligence of male and female students. There is significant difference in male $(\mathrm{M}=86.27, \mathrm{SD}=14.144)$ and female students $(\mathrm{M}=80.87$, $\mathrm{SD}=16.61 ; \mathrm{t}(228)=2.637, \mathrm{p}=.009)$ moral intelligence. On average, male students scored higher on the scale then their female counterpart. Since the p-value is less than .05 , it can therefore be concluded that there is significant difference in 
moral intelligence of male and female students.

Table 4. t-test of significant difference in moral intelligence of male and female students

\begin{tabular}{|c|c|c|c|c|c|c|c|}
\hline Sex & $\mathrm{N}$ & Mean & $\begin{array}{c}\text { Std. } \\
\text { Deviation }\end{array}$ & $\begin{array}{c}\text { Std. Error } \\
\text { Mean }\end{array}$ & $\mathrm{T}$ & $\mathrm{df}$ & $\mathrm{P}$ \\
\hline Male & 108 & 86.2685 & 14.14452 & 1.36106 & \multirow{2}{*}{2.637} & 228 & .009 \\
\hline Female & 122 & 80.8689 & 16.60675 & 1.50350 & & & \\
\hline
\end{tabular}

Research Objective 4: Do students differ in moral intelligence in relation to whoever they live with?

To answer this research question, students' scores on moral intelligence were subjected to a one-way analysis of variance (ANOVA) using whoever they living structures as factors. The result is presented in table $5 \mathrm{a}, \mathrm{b}$ and $\mathrm{c}$.

Table 5a. Analysis of variance of difference in moral intelligence of students across their living structure

\begin{tabular}{|c|c|c|c|c|c|}
\hline & $\begin{array}{c}\text { Sum of } \\
\text { Squares }\end{array}$ & df & $\begin{array}{c}\text { Mean } \\
\text { Square }\end{array}$ & F & Sig. \\
\hline $\begin{array}{c}\text { Between } \\
\text { Groups }\end{array}$ & 3710.273 & 4 & 927.568 & \multirow{2}{*}{3.904} & \multirow{2}{*}{0.004} \\
\cline { 1 - 4 } $\begin{array}{c}\text { Within } \\
\text { Groups }\end{array}$ & 52513.886 & 221 & 237.619 & & \\
\cline { 1 - 4 } Total & 56224.159 & 225 & & \\
\hline
\end{tabular}

Table 5a shows a one -way between groups analysis of variance conducted to explore the difference in moral intelligence of students living under different structure. Students were found under different living arrangements (Living with mother only as group 1; Father only 2; Father and mother together 3; Grandparents 4; and Guardians as fifth group. There was a statistically significant difference at the $\mathrm{p}<.05$ level in moral intelligence scores for students under the five different living arrangement: $F(4,221)=3.90$, $\mathrm{p}=.004$. The descriptive information and post-hoc test of students were shown in Table $5 \mathrm{~b}$ and $5 \mathrm{c}$ respectively.

Table 5b. Descriptive information of students on moral intelligence

\begin{tabular}{|c|c|c|c|c|}
\hline & $\mathrm{N}$ & Mean & $\begin{array}{c}\text { Std. } \\
\text { Deviation }\end{array}$ & Std. Error \\
\cline { 1 - 4 } Mother only & 28 & 77.1786 & 19.80844 & 3.74344 \\
\hline Father Only & 16 & 73.6875 & 18.79971 & 4.69993 \\
\hline $\begin{array}{c}\text { Father and } \\
\text { mother together }\end{array}$ & 153 & 85.8954 & 14.39214 & 1.16354 \\
\hline Grandparent & 17 & 82.8824 & 14.47792 & 3.51141 \\
\hline Guardian & 12 & 79.7500 & 12.72167 & 3.67243 \\
\hline Total & 226 & 83.3982 & 15.80776 & 1.05152 \\
\hline
\end{tabular}

Post-hoc comparisons using the Turkey HSD test indicated that the mean score for students living with mother only $(\mathrm{M}=77.18, \mathrm{SD}=19.81)$ was significantly different from those living with father and mother together $(M=85.89$, $\mathrm{SD}=14.39$ ). Mean score for students living with father only $(\mathrm{M}=73.69, \mathrm{SD}=18.79)$ was significantly different from those living with father and mother together $(\mathrm{M}=85.89$, $\mathrm{SD}=14.39$ ).
Table 5c. Post-hoc test of multiple comparisons of students' scores on moral intelligence across different living arrangements

\begin{tabular}{|c|c|c|c|c|}
\hline \multicolumn{5}{|c|}{$\begin{array}{c}\text { MI } \\
\text { Tukey HSD }\end{array}$} \\
\hline $\begin{array}{l}\text { (I) Whom do } \\
\text { you live with }\end{array}$ & $\begin{array}{l}\text { (J) Whom do } \\
\text { you live with }\end{array}$ & $\begin{array}{c}\text { Mean } \\
\text { Difference } \\
(\mathrm{I}-\mathrm{J})\end{array}$ & $\begin{array}{l}\text { Std. } \\
\text { Error }\end{array}$ & Sig. \\
\hline \multirow{4}{*}{ Mother only } & Father Only & 3.49107 & 4.83090 & .951 \\
\hline & $\begin{array}{c}\text { Father and } \\
\text { mother } \\
\text { together }\end{array}$ & $-8.71685^{*}$ & 3.16851 & .050 \\
\hline & Grandparent & -5.70378 & 4.73962 & .749 \\
\hline & Guardian & -2.57143 & 5.31865 & .989 \\
\hline \multirow{4}{*}{ Father Only } & Mother only & -3.49107 & 4.83090 & .951 \\
\hline & $\begin{array}{c}\text { Father and } \\
\text { mother } \\
\text { together }\end{array}$ & $-12.20792 *$ & 4.05022 & .024 \\
\hline & Grandparent & -9.19485 & 5.36925 & .428 \\
\hline & Guardian & -6.06250 & 5.88667 & .841 \\
\hline \multirow{4}{*}{$\begin{array}{c}\text { Father and } \\
\text { mother } \\
\text { together }\end{array}$} & Mother only & $8.71685^{*}$ & 3.16851 & .050 \\
\hline & Father Only & $12.20792 *$ & 4.05022 & .024 \\
\hline & Grandparent & 3.01307 & 3.94090 & .940 \\
\hline & Guardian & 6.14542 & 4.62111 & .673 \\
\hline \multirow{4}{*}{ Grandparent } & Mother only & 5.70378 & 4.73962 & .749 \\
\hline & Father Only & 9.19485 & 5.36925 & .428 \\
\hline & $\begin{array}{c}\text { Father and } \\
\text { mother } \\
\text { together }\end{array}$ & -3.01307 & 3.94090 & .940 \\
\hline & Guardian & 3.13235 & 5.81199 & .983 \\
\hline \multirow{4}{*}{ Guardian } & Mother only & 2.57143 & 5.31865 & .989 \\
\hline & Father Only & 6.06250 & 5.88667 & .841 \\
\hline & $\begin{array}{c}\text { Father and } \\
\text { mother } \\
\text { together }\end{array}$ & -6.14542 & 4.62111 & .673 \\
\hline & Grandparent & -3.13235 & 5.81199 & .983 \\
\hline
\end{tabular}

\section{Discussion of Findings}

The findings of this study revealed that the students had high level of moral intelligence. This indicates as Borba [16] and Sulaimon [17] noted that moral intelligence as the capacity to understand right from wrong. This may therefore make one to conclude that the students' moral value which involves applying ones principles into action may correlates with cheating in examinations. The findings also showed that there was a significant relationship between moral intelligence and perception to examination malpractice. This supported the earlier findings by Olasehinde-Williams et al.[18] \& Hoseinpoor et al.[30] that moral reasoning correlates with academic integrity. Also Borba [16], Osborn [35], and Beheshtifar et al.[36] were of the opinion that moral intelligence will affect academic performance. The seven essential virtues of moral intelligence will help the students to do what is right and resist any pressures that may defy the habits of good character. 
The result also revealed significant differences in moral intelligence between males and females. This corroborated the earlier findings by Hoseinpoor et al.[30] \& Olasehinde-Williams et al.[20], that significant differences exists in moral reasoning across gender. The study also showed that the significant differences exist in moral intelligence of the students on the basis of family structure. This was supported by child Uwaifo [25] and Demuth et al.[26]. They discovered that the influence of parent- child relationship cannot be overemphasised in moral development of the child.

\section{Recommendations}

Psychologists regard intelligence as the ability to function effectively in the world. Intelligent people are those who have a store of knowledge and skills gained from experience that allow them to manage efficiently the tasks of daily life. Therefore;

1. There is the need for mainstreaming values education into school curricular at every stage of education in the country, so as to boost students' tendency to take action consistent with their moral reasoning. Morality can be taught in schools e.g. via class discussions and working through real-life problems

2. To create a true culture and show institutional endorsement, of academic integrity in schools, a well-structured mentoring program in which lecturers are encouraged to model appropriate ethical standards in their respective areas of specialization should be evolved.

3. Teachers should arouse and sustain the attention of the students during classroom discussion. The experiences as noted by Hoseinpoor et al.[30] have shown that lazy students tell lie easily making excuses at their tasks.

4. Classroom interactions and team work should be encouraged. It is certainly conceivable that teachers who participate in flourishing teams will be more likely to model good moral behaviours in the classroom and be more sensitive to their expression in their students. This is because students with high honesty have more friends and other students respect and connecting them easily.

5. There should be adequate collaboration between the parents and the school. It has been found that family structures play significant role in moral development of the child. That is, family composition has major implications for the life course of children and their well-being. There is also the need to keep enlightening the parents of the importance of the home structure on the life of children. This is necessary so that parents can understand the implications and consequences of parental separation and thus mobilize all resources to curtail the problems arising from the situation.

6. Finally, school counsellors should be employed in institutions of learning and adequate supervision to be put in place to ensure provision of necessary guidance services to students. Counselling psychologists and school's counsellors should work on the moral well-being of students in the school.

\section{Appendix}

Pie charts depicting socio-demographic variables of the student
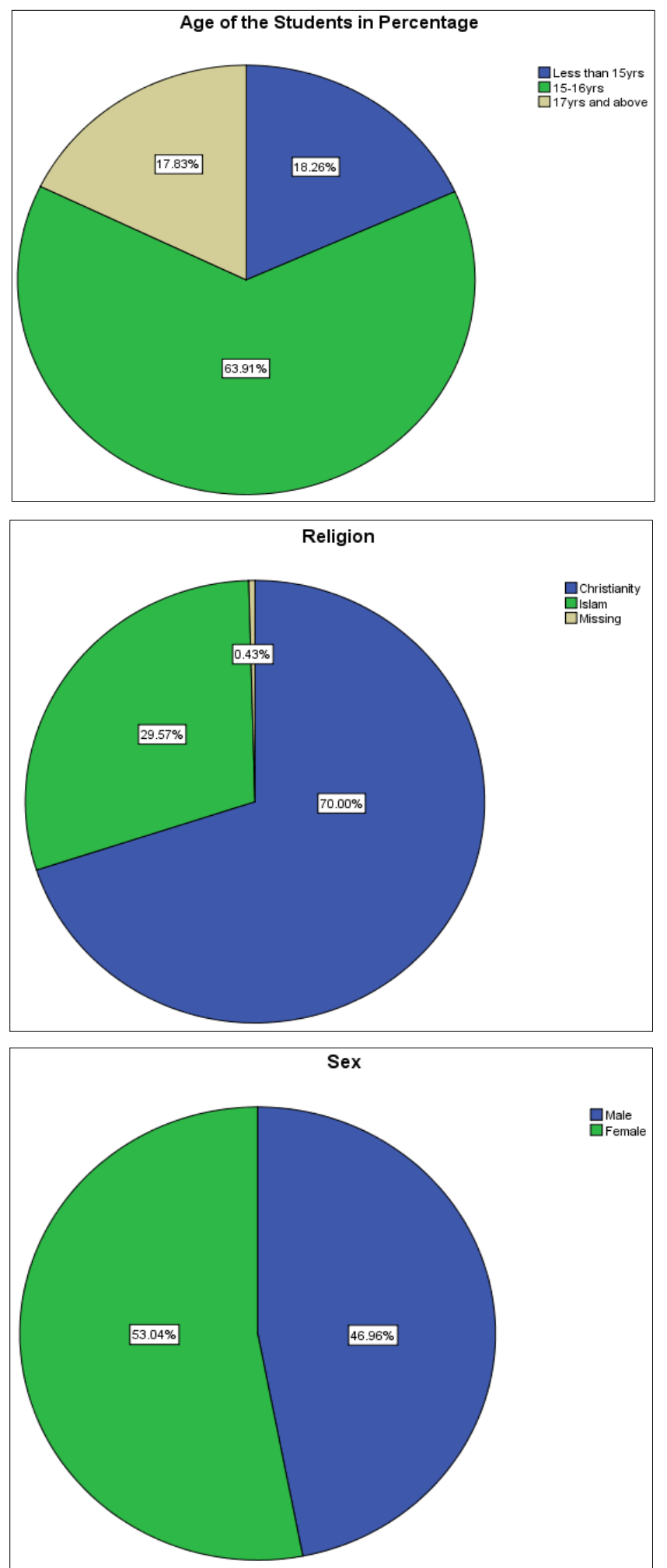

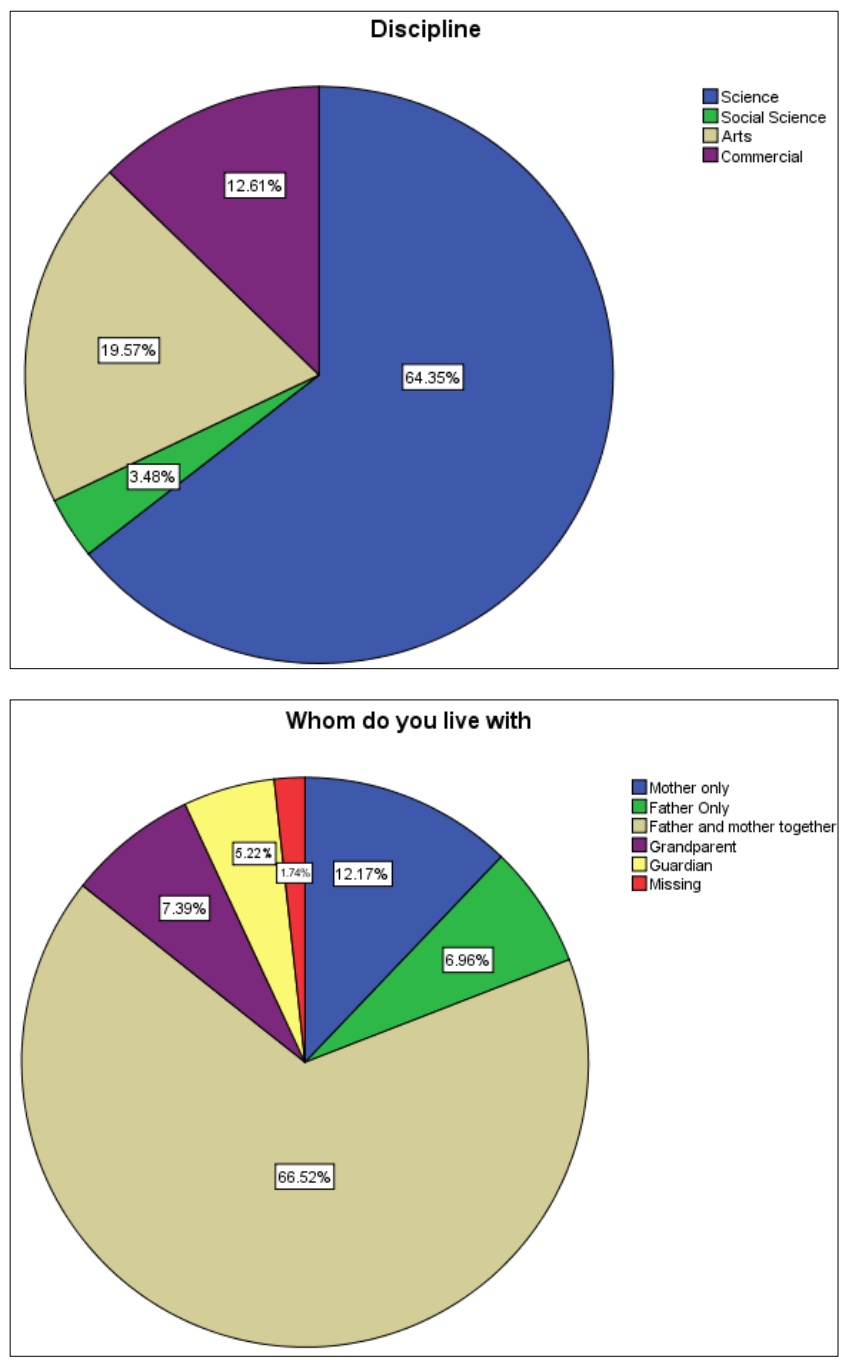

\section{REFERENCES}

[1] Mkpa, MA. Quality Control in the Conduct of Examination in our Institutions. Paper Presented at a Workshop Organised by Federal College of Education (Technical) Umunze for her academic staff, 2002 May 28

[2] Aliyu, J, Adeoye, J. Examination Cheating among College Students: A Case Study of Advanced Teachers College A.B.U. Teachers Education Journal, 1995;1.1(1)

[3] Unigwe, S. C. Examination Ethics Projects as an Antidote to Malpractice in Schools and Implications for Teacher Training. Journal of The Nigerian Society for Educational Psychologists (NISEP) 2006, 4 (1)164-172

[4] Bankole, D. O. Nigerian Education and the Menace of Examination Malpractice. The Way Out. Education periscope, 2005:1,125-130.

[5] Hiko, M. A. Examination Malpractice Causes and Implication. A paper Presented at the occasion of 2007/2008-session orientation for 100 level students, 2008: March 11.

[6] Kpangban E, Ajaja, OP., \& Umudhe, SE. Sound Moral
Values and Development of Right Attitudes as a Panacea to Examination Malpractice in Nigeria. Kamla-Raj Journal of Social. Science, 2008: 17(3): 223-131

[7] Money VO. The Effects of Principals' Management Behaviour on Incidence of Exam Malpractices in Warri South L.G.A of Delta state. Unpublished M.ED Project, Delta state University, Abraka; 1997.

[8] Cable Network News (2003). Survey: Many Students Say Cheating is O.K. Retrieved from http://www. CNN.com.

[9] Olugbile S. Exam Malpractice rocks Zamfara, Lagos: Punch Education, The Punch 17 (19166) Friday, September 10, 2004.

[10] Vanguard(2013)Jamb Releases 2013 UTME Results http://www.vanguardngr.com/2013/05/jamb-releases-2013-u tme-results-

withholds-12110-results/\#sthash.mWXVnew9.dpuf

[11] Onokoya AY. (2006). A study of Students' Perception of Examination Cheating, Attitude to Cheating and Examination Behaviours among Students of Covenant University, Ota. Ogun state. Journal of The Nigerian Society for Educational Psychologists (NISEP) 2006, 4 (1)143-152)

[12] Fagbemi JO. Assessment and Examination Malpractices. Paper presented at ACNAE 2001 Proceedings of the $16^{\text {th }}$ Annual Congress of the Nigeria Academy of Education 2001;82-93.

[13] World Bank (2005). Public Examination System: Malpractice. Retrieved April, 10th, 2013 from

http://www.filepublic\%20examinationsystem $\% 20 \% 20$ topics $\% 220520$ world\%20bank, htm

[14] Mustapha, A. Y. (2001). Teaching Test-Wiseness as an Integral Part of Classroom Instruction in Nigeria Schools: The Teacher's Role. Paper presented at ACNAE 2001 Proceedings of the $16^{\text {th }}$ Annual Congress of the Nigeria Academy of Education 2001;82-93.

[15] Lennick D, Kiel F. Moral Intelligence: Enhancing Business Performance \& Leadership Success. Upper Saddle River, NJ: Wharton School Publishing, Pearson Education.2008

[16] Borba, M. (2001). Building Moral Intelligence: The seven essential virtues that teach kids to do the right thing. California, Jessey-Bass. 2001

[17] Sulaimon (2010) Examination Malpractice: Causes and Solutions. Retrieved from http;//pmnewsnigeria.com on $13 / 2 / 2012$

[18] Olasehinde-Williams O, Olawuyi O, Yahaya LA. (2011). Gender and Age Variations in Perceptions of Situational Appropriateness of Academic Integrity among Students in Kwara State, Nigeria. International Journal of Psychology and Counselling .2011; 3(4), 62-70 Retrieved from http://www.academicjournals.org/IJPC on May 24th 2014

[19] Leming JS. (1980). Cheating behaviour, subject variables and components of the internal- external scale under high and low risk conditions. Journal of Educational Research, 1980; $74,83-87$.

[20] Olasehinde-Williams FAO, Abdullahi OE, Owolabi HO. The Relationships Between Background Variables and Cheating Tendencies among Students of a Federal University in Nigeria. Nigerian Journal of Educational Foundations, 2003; 6(1): 64-75. 
[21] Ones DS, Chockalingan V. Gender, Age, and Race Differences on Overt Integrity Tests: Results across four large-scale job applicant datasets. Journal of Applied Psychology, 1998; 83(1): 35-42.

[22] Lobel TE. Gender Differences in Adolescents' Cheating Behaviour: An International Model. Personality and Individual. Differences, 1993;14(1): 275- 277

[23] Braseth RB. Academic Dishonesty among Undergraduate Journalism Students. An Unpublished Thesis submitted to the University of Mississippi. 1996

[24] Evans ED, Craig D. Adolescent Cognitions for Academic Cheating as a Function of Grade Level and Achievement Status. In B Bough \& L. Tommaso editors. Are college cheating and plagiarism related to academic procrastination? 1980 Psychol. Rep., 77: 691- 698

[25] Uwaifo VO. The Effects of Family Structures on the Academic Performance of Nigerian University Students. Global Journal of Human Social Science, 2012; 12 (5)

[26] Demuth S, Brown SL. Family Structure, Family Process, and Adolescent Delinquency: The Significance of Parental Absence Versus Parental Gender. Journal of Research in Crime and Delinquency, 2004; 41 (1), 58-81.

[27] Bronte-Tinkew J, Moore KA, Capps RC, Zaff J. The Influence of Father Involvement on Youth Risk Behaviours among Adolescents: A Comparison of Native Born and Immigrant Families. Social Science Research, 2006; 35, 181-209.

[28] Kelly JB. Children's Adjustment in Conflicted Marriage and Divorce: A decade review of research. Journal of the American Academy of child and Adolescent Psychiatry, 2000;
$39,963-973$.

[29] Freeman J. Morality and Giftedness in T. Balchin, B. Hymer, \& Mathews, D. (Eds.) The Routledge International Companion to Gifted Education. London and New York: Routledge. 2008

[30] Hoseinpoor Z, Ranjdoost S. The Relationship Between Moral Intelligence and Academic Progress of Students Third Year of High School Course in Tabriz City Advances in Environmental Biology, 2013; 7(11), 3356-3361

[31] Self DJ, Ellison EM. Teaching Engineering Ethics: Assessment of its Influence on Moral Reasoning Skills. Journal of Engineering Education January 1998

[32] Self DJ, Baldwin Jr. DC, Wolinsky FD. Evaluation of Teaching Medical Ethics by an Assessment of Moral Reasoning. Medical Education, 1992; 2, 178-184.

[33] Martin DE, Austin B. Validation of the Moral Competency Inventory Measurement Instrument: Content, Construct, Convergent and Discriminant Approaches. Proceedings of $A S B B S, 2008 ; 15(1)$

[34] Ejide B. Examination Malpractice in a Corrupt System: A part or apart? Students View. Journal of the Nigerian Society for Educational Psychologists (NISEP) 2006; 4 (1) 120-131.

[35] Osborn TN. Moral Intelligence. TEAM International. 2011 Retrieved on April 23 ${ }^{\text {rd }}, 2014$ from www.teaminternational.net

[36] Beheshtifar M., Esmaeli Z, Moghadam MN. Effect of Moral Intelligence on Leadership. European Journal of Economics, Finance and Administrative Sciences. 2011; 43 Retrieved on June $15^{\text {th }}, 2014$ from http://www.eurojournals.com/EJEFAS .htm 